\title{
Forest structure of artificial islands in the Tucuruí dam reservoir in northern Brazil: a test core-area model
}

\author{
Leandro V. FERREIRA, Selvino NECKEL-OLIVEIRA², Ulisses GALATTI ${ }^{3}$, Sarita B. FÁVERI ${ }^{4}$, Pia PAROLIN ${ }^{5}$
}

\begin{abstract}
Construction of hydroelectric dams in tropical regions has been contributing significantly to forest fragmentation. Alterations at edges of forest fragments impact plant communities that suffer increases in tree damage and dead, and decreases in seedling recruitment. This study aimed to test the core-area model in a fragmented landscape caused by construction of a hydroelectric power plant in the Brazilian Amazon. We studied variations in forest structure between the margin and interiors of 17 islands of 8-100 hectares in the Tucuruí dam reservoir, in two plots (30 and >100m from the margin) per island. Mean tree density, basal area, seedling density and forest cover did not significantly differ between marginal and interior island plots. Also, no significant differences were found in liana density, dead tree or damage for margin and interior plots. The peculiar topographic conditions associated with the matrix habitat and shapes of the island seem to extend edge effects to the islands' centers independently of the island size, giving the interior similar physical microclimatic conditions as at the edges. We propose a protocol for assessing the ecological impacts of edge effects in fragments of natural habitat surrounded by induced (artificial) edges. The protocol involves three steps: (1) identification of focal taxa of particular conservation or management interest, (2) measurement of an "edge function" that describes the response of these taxa to induced edges, and (3) use of a "Core-Area Model" to extrapolate edge function parameters to existing or novel situations.
\end{abstract}

KEYWORDS: core-area model, forest edges, fragmentation, hydroelectric dams

\section{Estrutura da floresta em ilhas artificiais no reservatório da Usina Hidrelé- trica de Tucuruí, Brasil: Um teste do modelo de área nuclear}

\section{RESUMO}

A construção de usinas hidrelétricas em regiôes tropicais tem contribuído significativamente para a fragmentação da floresta. As alteraçóes nas bordas de fragmentos florestais causam profundos impactos na comunidade de plantas, tais como, o aumento em de árvores mortas ou danificadas e a diminuição do recrutamento de plântulas. Este estudo tem como objetivo testar o modelo de área nuclear (core-area model) em uma paisagem de floresta fragmentada resultante da formaçáo do lago da Usina Hidrelétrica de Tucucui na Amazônia. Foram medidas as variaçôes na estrutura em 17 ilhas, com tamanhos variando de 8 a 100 hectares. Em cada ilha foram colocadas duas parcelas, a $1^{\text {a }}$ parcela a 30 metros da margem e a $2^{\text {a }}$ parcela a mais de 100 metros da margem da ilha. A densidade e a área basal de árvores, a densidade da regeneraçáo natural e a cobertura do dossel da floresta não foram significativamente diferentes entre as parcelas da borda e do interior das ilhas. Também não foram encontradas diferenças significativas na densidade de lianas, no número de troncos mortos ou árvores danificadas entre as parcelas da borda e do interior das ilhas. A grande declividade do terreno das ilhas, a matriz circundante (água) e a forma irregular da ilhas podem ser os fatores responsáveis me provocar a extensáo do efeito de borda em todas as ilhas analisadas, independente do tamanho e grau de isolamento. Nós propomos um novo protocolo para avaliar os impactos ecológicos dos efeitos de borda em fragmentos de habitat criados artificialmente. Este protocolo envolve três etapas: (1) identificação dos táxons biológicos de particular interesse de conservação ou de gestão (2) medição das das variáveis responsaveis pela resposta dos táxons induzidas pelo efeito de borda e (3) Usar o modelo de área nuclear (core area model) na extrapolação das variáveis medidas em situacóes novas ou existentes.

PALAVRAS CHAVES: modelo de área nuclear, efeito de borda, fragmentação, usinas hidrelétricas.

\footnotetext{
1 Museu Paraense Emílio Goeldi, email:Ivferreira@museu-goeldi.br

2 Universidade Federal de Santa Catarina, email: neckel@ccb.ufsc.br

3 Museu Paraense Emílio Goeldi email:ulisses@museu-goeldi.br

${ }^{4}$ Universidade Federal de Santa Catarina, email: sarita@ccb.ufsc.br

${ }^{5}$ Institut National de la Recherche Agronomique (INRA), email:pia.parolin@sophia.inra.fr
} 


\section{INTRODUCTION}

Forest fragmentation in tropical regions shows great variation in physical and biological aspects (Lovejoy et al. 1983; Kapos 1989; Williams-Linera 1990; Benítez-Malvido 1998; Laurance et al. 2002), mainly due to the creation of edges and decreases in forest cover and matrix quality. Physical effects include radiation flux, air and soil humidity and temperature, wind speed, and water flux in soil and air (Kapos 1989; Williams-Linera 1990; Camargo and Kapos 1995). Biological effects include alterations at the edges of forest fragments that impact plant communities, leading to increases in dead tree and damage and decreases in seedling recruitment (Ferreira and Laurance 1997; Viana et al. 1997; Laurance et al. 1998).

Edge effects are one of the most important factors, and change environmental conditions at different distances inside forest fragments, depending on their size and shape, the age of the edge, type of secondary forest around the fragment, and regional land use (Kapos 1989; Williams-Linera 1990; Miller et al. 1991). In a Panamanian forest, changes in forest structure and dead tree were higher on the first $15 \mathrm{~m}$ from the border than on the fragment interior (Williams-Linera 1990). In Central Amazonian forest fragments Ferreira and Laurance (1997) observed high dead tree and damage up to $100 \mathrm{~m}$ from an edge. In the same study area, Kapos (1989) reported changes in microclimatic conditions extending up to 60 to $100 \mathrm{~m}$ into the interior of recently isolated forest fragments.

The core-area model was proposed by Laurance and Yensen (1991) to predict the impacts of edge effects on vegetation structure in fragments of varying sizes and shapes. The model suggests that edge effects will increase in forest remnants with irregular shapes. However, this model may not be representative of most forest fragments, as it has only been tested on a single landscape in the Amazon, where the fragments are square and the shape index is close to 1 (Ferreira and Laurance 1997). Ferreira and Laurance (1997) suggest that edge effects are more apparent when realistic fragment shapes are used in the model, rather than when an untypical landscape is used like the one in their study site.

Much of the southeast of the Brazilian state of Pará State is highly fragmented due to anthropogenic activities such as mining, farming, agriculture and hydroelectric dams. The construction of hydroelectric dams sometimes takes place in large hilly valleys, resulting in numerous isolated forest patches on islands that form from the higher points of the local topography. Although a large number of hydroelectric dams are projected to be built in the tropics (Wu et al. 2004), few biological studies have been carried out in the isolated forest fragments on islands in the reservoirs of dams (Terborgh et al. 2006; Lopez and Terborgh 2007; Brandão and Araujo 2008) and no study has been made on the edge effects in the forest structure of the isolated forest fragments in this system type.

To test the core-area model proposed by Laurance and Yensen (1991), we designed a study to determine variations in forest structure between the margin and interiors of islands of different sizes and shapes in the Tucuruí dam reservoir in the Para state in northern Brazil. Specifically, variations in tree density, basal area, seedling density, forest cover, liana density, dead tree and damage in paired marginal and interior island plots were used to characterize the edge effects on forested islands. These variables were compared between margin $(<100 \mathrm{~m})$ and interior $(>100 \mathrm{~m})$ plots from forest edges created in 1984 and 1985. The classification of plots into margin and interior was based on previous studies of forest dynamics indicating that most edge effects penetrate up to $100 \mathrm{~m}$ from the edge (Ferreira and Laurance 1997; Laurance et al. 1998; Vasconcelos and Luizão 2004).

\section{MATERIALS AND METHODS}

\section{Study site}

This study was conducted in forest remnants on islands in the Tucuruí Dam reservoir in Para State, northern Brazil $\left(3^{\circ} 43^{\prime}\right.$ to $5^{\circ} 15^{\prime} \mathrm{S}$; $49^{\circ} 12^{\prime}$ to $\left.50^{\circ} 00^{\prime} \mathrm{W}\right)$. This artificial lake was formed in 1984 and 1985, and it flooded an area of upland forest of approximately $2.918 \mathrm{~km}^{2}$ (Eletronorte 2000). This resulted in the creation of more than 2.200 islands of different sizes, shapes and degrees of isolation (Figure 1).
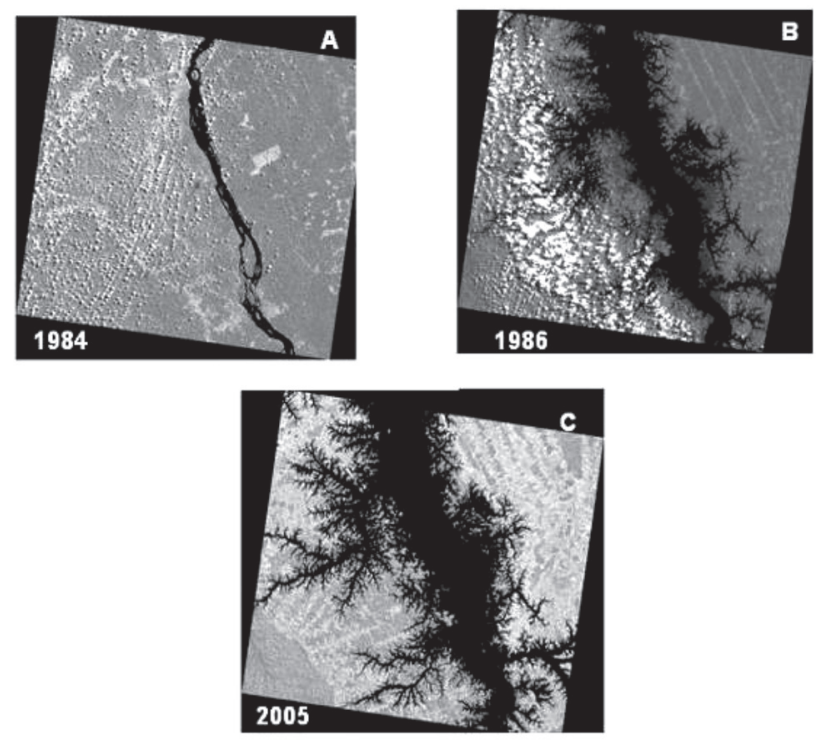

Figure 1 - Sequence of satellite images showing the Tocantins river before the construction of Tucurui Dam $(A)$ in 1984, during the process of filling of the lake in 1986 (B) and the actual shape of the lake, showing thousand of islands since $2005(\mathrm{C})$. 
The climate of the region is characterized by marked seasonality with a rainy season from December to May and a dry season from June to November. Annual precipitation varies between $1800-2300 \mathrm{~mm}$ (Morais et al. 2005), with a yearly average temperature of $24^{\circ} \mathrm{C}$ (Eletronorte 2000).

\section{Site selection}

We used a satellite image to choose seventeen islands on the right margin of the Tucuruí reservoir (Figure 2). The criterions for inclusion were size, shape, degree of isolation, and conservation status of the island. We selected small-medium size, completely isolated, near rounded and relatively undisturbed islands. The elevations of the islands from the margin to the interior varied from 8 to 31 meters $(19.5 \pm 6.2 \mathrm{~m})$ and was it determined using GPS (Garmin Map 76CS). The shape index (SI) was calculated using the formula SI=Perimeter of island $/$ Varea of island $\mathrm{x} 4$ (Hermann et al. 2005).

On each island two plots of $5 \times 40 \mathrm{~m}$ were laid out, one plot at $30 \mathrm{~m}$ from the margin, and the other in the interior of the island at more than $100 \mathrm{~m}$ from the margin. In the plots, counts and measurements were made of all trees and vines with Diameter at Breast Height $(\mathrm{DBH}) \geq 5 \mathrm{~cm}$. Dead
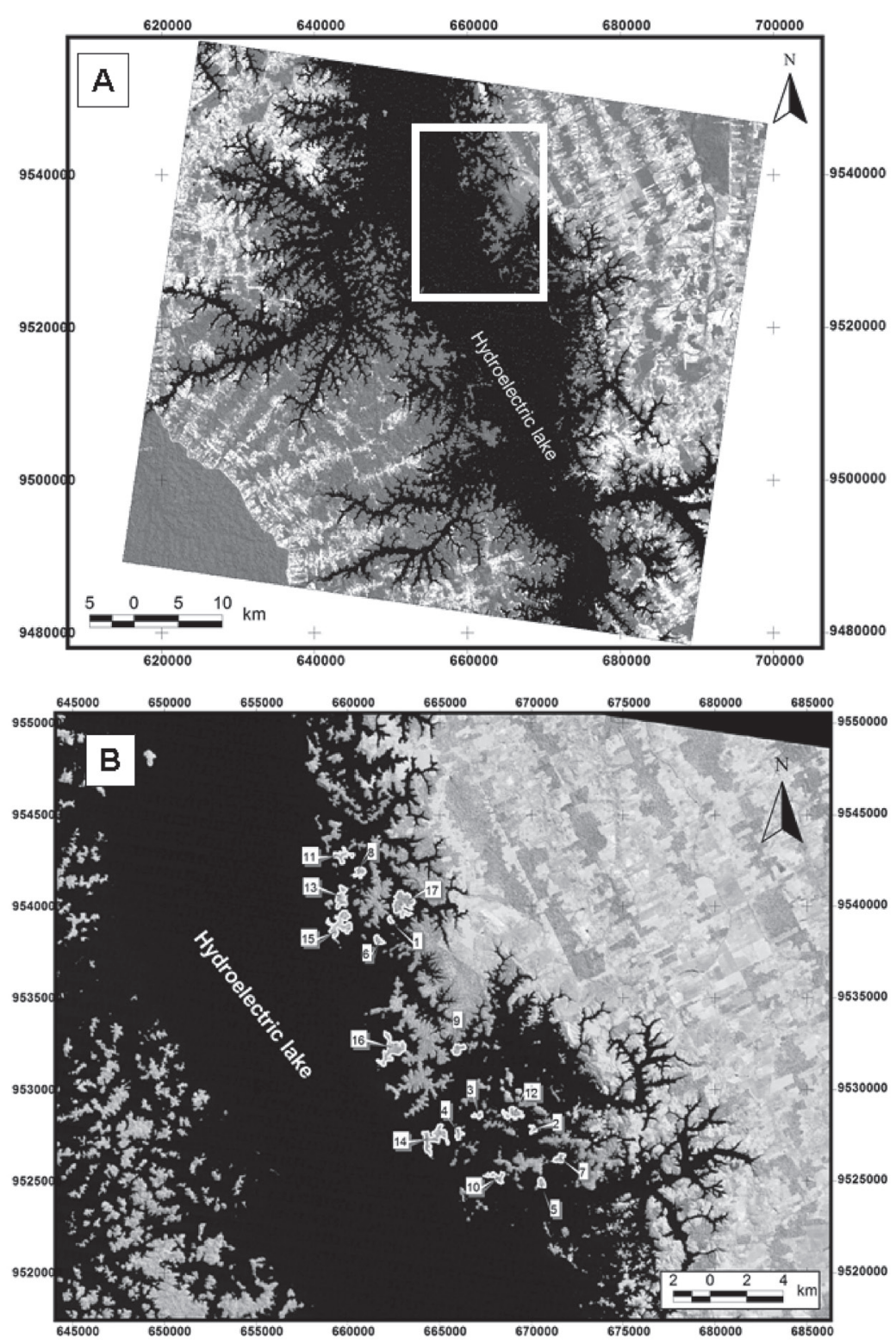

Figure 2 - Satellite image of the Tucuruí reservoir (A) showing in detail the 17 islands used in this study (B) 
trees, both standing and fallen, were counted, and damage to trees (broken crown or trunk) was quantified. Within each plot, two subplots of $1 \mathrm{~m}$ by $1 \mathrm{~m}$ were laid out to measure seedlings until $30 \mathrm{~cm}$ in height. The forest cover of each plot was estimated using a digital camera and calculated using the geographic information program Arcview 3.3 (ESRI 2002).

\section{Statistical analyses}

Paired t-tests were used to test differences in tree density, tree basal area, seedling density, and forest cover of plots (dependent variables) in the two conditions (margin and interior of islands). Vine density and dead tree and damage were analyzed using the Wilcoxon non-parametric test. Ancova was used to test if the size and the shape of islands influenced the mean tree densities at island margins or interiors. Habitat type was a category variable, while island area and shape index (SI) was continuous variables and were tested separately. All analysis was performed in Systat 10 (Wilkinson 1986).

\section{RESULTS AND DISCUSSION}

All islands used in this study were characterized by large trees of 20 to $27 \mathrm{~m}$ height, and an understory dominated by several palm species. The sizes of selected islands varied from 7.9 to 102.6 hectares and the shape index varied from 1.12 to 2.09 (Table 1).

Table 1 - Size (hectares), altitude $(\mathrm{m})$ and shape index of the studied islands in the Tucuruí dam.

\begin{tabular}{|c|c|c|c|}
\hline Island number & Size (ha) & Altitude (m) & Shape index \\
\hline 1 & 7.9 & 10 & 1.12 \\
\hline 2 & 10.1 & 15 & 1.42 \\
\hline 3 & 12.9 & 31 & 1.27 \\
\hline 4 & 16.6 & 17 & 1.38 \\
\hline 5 & 16.8 & 15 & 1.07 \\
\hline 6 & 17.6 & 18 & 1.13 \\
\hline 7 & 21.4 & 25 & 1.15 \\
\hline 8 & 22.4 & 18 & 1.41 \\
\hline 9 & 28.8 & 17 & 1.17 \\
\hline 10 & 29.7 & 28 & 1.66 \\
\hline 11 & 35.3 & 18 & 1.91 \\
\hline 12 & 41.6 & 27 & 1.85 \\
\hline 13 & 47.6 & 19 & 1.57 \\
\hline 14 & 90.2 & 8 & 2.05 \\
\hline 15 & 91.3 & 20 & 2.09 \\
\hline 16 & 99.1 & 26 & 1.92 \\
\hline 17 & 102.6 & 19 & 1.69 \\
\hline
\end{tabular}

Mean tree density $(\mathrm{t}=2.033, \mathrm{P}=0.06)$, basal area $(\mathrm{t}=1.072$; $\mathrm{P}=0.299)$, seedling density $(\mathrm{t}=-0.278, \mathrm{P}=0.785)$ and forest cover $(t=-1.003, P=0,397)$ were not significantly different between marginal and interior island plots (Table 2).

Tree densities were not significantly different between marginal and interior island plots in relation to island size (Ancova: $\mathrm{F}_{[1,31]}=0.095 ; \mathrm{P}=0.760$ ) and island shape index (SI) (Ancova: $\mathrm{F}_{[1,31]}=0.022 ; \mathrm{P}=0.884$ ).

No significant differences were found in liana density $(\mathrm{Z}=-1.922, \mathrm{P}=0.06)$, dead tree $(\mathrm{Z}=-1.699, \mathrm{P}=0.09)$ or tree damage $(Z=-1.599, P=0.119)$ between marginal and interior island plots. The liana density varied from 0 to 7 in marginal to 0 to 4 in interior island plots; dead tree varied 0 to 6 in marginal to 0 to 6 in interior island plots; tree damage varied 1 to 15 in marginal to 0 to 9 in interior island plots.

The observed lack of significant differences in the dependent variables, between the edge and interior of islands, supports the core-area model (Laurance and Yensen 1991). Small to medium size islands in the Tucurui dam are characterized by a marked variation in shape index (1 to 2 ), and have a steep topography near the shoreline and a narrow and flat forest floor at the center of each island. The high shape index and peculiar topography are associated with the matrix habitat (water), which probably extends edge effects to the island centers independently of the island size, giving the interior similar physical microclimatic conditions as the edges. Previous studies carried out in the Central Amazon found significant differences in vegetation structure (Ferreira and Laurance 1997) and litter fall production (Vasconcelos and Luizáo 2004) between marginal and interior plots in the fragmentation landscapes. These Central Amazon fragments are shaped as squares and consequently have a shape index close to 1 . These characteristics are likely to have had a strong influence on the results found by Ferreira and Laurance (1997).

\section{Ecological implications for reservoir islands}

Such a finding could have great impact on the conservation of local biodiversity, since the forest structure of the islands analyzed in this study indicates that edge effects extend for the entire islands (Figure 3).

Table 2 - Mean and Standard Deviation of tree density, tree basal area, seedling density, and forest cover in the marginal and interior plots of the studied islands in the Tucuruí dam.

\begin{tabular}{lcc}
\hline \multirow{2}{*}{ Variables measured } & \multicolumn{2}{c}{ Mean and Standard Deviation } \\
\cline { 2 - 3 } & Marginal plots & Interior plots \\
\hline tree density $\left(200 \mathrm{~m}^{2}\right)$ & $42.1 \pm 7.0$ individuals & $36.9 \pm 10.4$ individuals \\
Basal area $\left(200 \mathrm{~m}^{2}\right)$ & $9.4 \pm 0.3 \mathrm{~cm}$ & $8.0 \pm 3.7 \mathrm{~cm}$ \\
Seedling density $\left(200 \mathrm{~m}^{2}\right)$ & $13.7 \pm 9.8$ indivíduals & $14.4 \pm 7.4$ individuals \\
Forest cover $(\%)$ & $82.3 \pm 7.3 \%$ & $89.3 \pm 3.7 \%$ \\
\hline
\end{tabular}




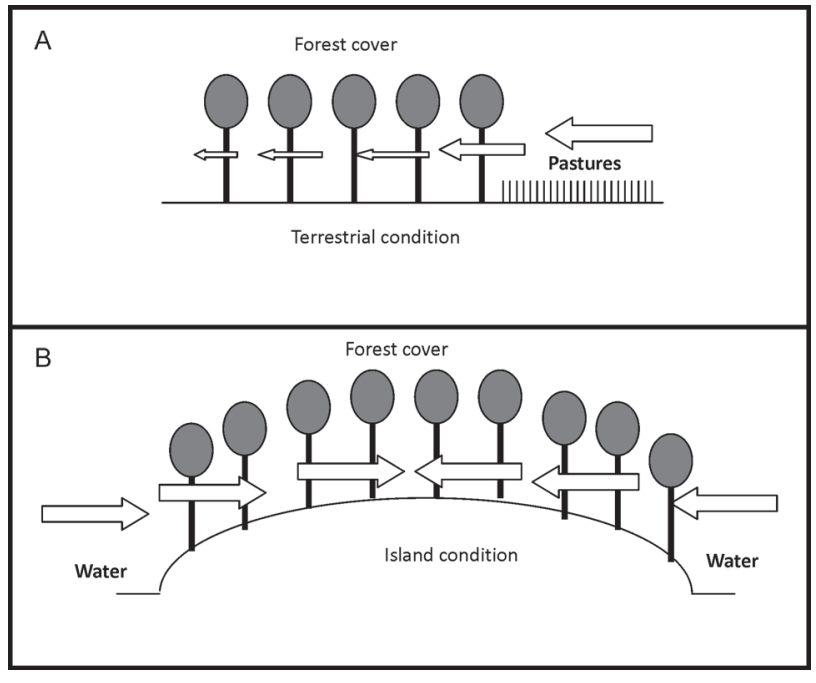

Figure 3 - Edge effect in two situations: terrestrial region with flat topography (A) and an island in the Tucurui reservoir (B). Arrows of different sizes indicate relative decrease of the edge effects in relation to distance.

In the long term this may lead to alterations in patterns of species richness, diversity, and floristic composition of plant communities, because isolated forest fragments do not sustain the same species richness and diversity originally found in surrounding unfragmented primary forests (Murcia 1995; Laurance 1998). Changes in forest structure can also affect ecological processes such as pollination, predator territorial behavior, and animals' dietary habits (Laurance 1991), resulting in a fall in plant and animal diversity and, in extreme cases, local defaunation (Turner 1996). In a study made at an artificial island in Guri Lake, Venezuela, found high number of dead saplings in all island sizes, while the number of dead trees was negatively associated with area size (Terborgh et al. 2006). These results were attributed to herbivores, as they imply that the impact is more severe at earlier stages of regeneration.

By definition, the dominant matrix in all reservoir islands is water. This may create an ecological barrier that impedes the recolonization by many animal species that may be important to tree pollination or seed dispersal (Filho e Metzger 2006).

The results of this study are particularly worrying as the islands resulting from the creation of hydroeletric reservoirs in Amazonia have been proposed to act as protected areas for the conservation of forest biodiversity in the region.

\section{CONCLUSIONS}

Some care should be used in extending these results. The largest island used in this study was only 103 hectares in size, and larger islands on both sides of the Tucuruí reservoir should be investigated to determine if their interior portions have edge-like microclimatic conditions and are adequate to maintain viable populations of species. Another possible interpretation of the data obtained in this study is that the edge effects do not have much importance in the Tucurui island. However, this study does not really allow to determine whether this is the case or not. To further understand the functioning of forests on artificial islands, we suggest long-term floristic and biodiversity monitoring, using permanent plots on islands of different sizes, shapes, and degrees of isolation to study how edge effects and isolation affects the maintenance of local biodiversity.

\section{ACKNOWLEDGMENTS}

This work was undertaken in the context of the joint project to evaluate and monitor vertebrate communities of the Tucuruí dam reservoir, supported by the Centrais Elétricas do Norte do Brasil S.A. (Eletronorte) and the Museu Paraense Emílio Goeldi. Data collection was carried out in part by master students of the field course in "Conservation and Population Ecology in Forest Fragments". Special thanks to Drs. William Laurance, Willian Overal, Jos Barlow and Rubens Ghilardi Júnior by critical and suggestion in this manuscript.

\section{REFERENCES}

Benítez-Malvido, J. 1998. Impact of forest fragmentation on seedling abundance in a tropical rain forest. Conservation Biology, 12: 380-389

Brandão, R.; Araujo, A.F.B. 2008. Changes in anuran species richness and abundance resulting from hydroelectric dam flooding in Central Brazil. Biotropica, 40: 263-266.

Camargo, J.L.C.; Kapos, V. 1995. Complex edge effects on soil moisture and microclimate in central Amazonian forest. Journal of Tropical Ecology, 11: 205-221.

Eletronorte 2000. Macrozoneamento da Área de Influência a Montante do lago Reservatório da Usina Hidrelétrica de Tucuruí. Documento base para discussóes Tucuruí Pará 145pp.

ESRI (Environmental Systems Research Institute) 1996. Arc View GIS. The Geographic Information System for Everyone.

Ferreira, L.V.; Laurance, W.F. 1997. Effects of forest fragmentation on mortality and damage of selected trees in Central Amazonia. Conservation Biology, 11: 797-801.

Filho, J.F.O.; Metzger, J.P. 2006. Thresholds in landscape structure for three common deforestation patterns in the Brazilian Amazon. Landscape Ecology, 21: 1061-1073.

Hermann, C.H.; Rodrigues, E.; Lima, A. 2005. A paisagem como condicionadota de bordas de fragmentos florestais. Floresta 35: 13-22.

Kapos, V. 1989. Effects of isolation on the water status of forest patches in the Brazilian Amazon. Journal of Tropical Ecology, 5: 173-185.

Laurance, W.F.; Yensen, E. 1991. Predicting the impacts of edge effects in fragmented. Biological Conservation, 55: 77-92. 
Laurance, W.F. 1998. A crisis in the making: responses of Amazonian forests to land use and climate change. Trends in Ecology and Evolution, 13: 411-415.

Laurance, W.F.; Gascon, C.; Rankin-De Merona, J.M. 1998. Predicting effects of habitat destruction on plant communities: a test of a model using Amazonian trees. Ecological Applications, 9: 548-554.

Laurance, W.F. 1991. Edge effects in tropical forest fragments: application of a model for the design of nature reserves. Biological Conservation, 57: 205-219.

Laurance, W.F.; Lovejoy, T.E.; Vasconcelos, H.L.; Bruna, E.M.; Didham, R.K.; Stouffer, P.C.; Gascon, C.; Bierregaard, R.O.; Laurance, S.G.; Sampaio, E. 2002. Ecosystem decay of Amazonian forest fragment: a 22-year investigation. Conservation Biology, 16: 605-618.

Lopez, L.; Terborgh, J. 2007. Seed predation and seedling herbivory as factors in tree recruitment failure of predator-free forest islands. Journal of Tropical Ecology, 23: 129-137.

Lovejoy, T.E.; Bierregaard, R.O.; Rankin-De-Merona, J.M.; Shubart, H.O.M. 1983. Ecological dynamics of tropical forest fragments. Pp:377-384 in Sutton, S.L.; Whitmore, T.C.; Chadwith, A.C. (eds) Tropical rain forest: Ecology and Management. Blackwell Scientific Oxford.

Miller, D.R.; Lin, J.D.; Lu, Z.N. 1991. Some effects of surrounding forest canopy architecture on the wind field in small clearings. Forest Ecology and Management, 45: 79-91.

Morais, B.C.; Costa, J.M.N.; Costa, A.C.L.; Costa, M.H. 2005. Variação espacial e temporal da precipitação no Estado do Pará. Acta Amazonica, 35: 207-214.
Murcia, C. 1995. Edge effects in fragmented forests: implications for conservation. Trends in Ecology and Evolution, 10: 58-62.

Terborgh, J.; Nuñez, V.P.; Baulukian, B.; Silman, M.R. 2006. Vegetation dynamics of predator-free land-bridge islands. Journal of Ecology, 94: 253-263.

Turner, I.M. 1996. Species loss in fragments of tropical rain forest: a review of the evidence. Journal of Applied Ecology, 33: 200-209.

Vasconcelos, H.L.; Luizão, F.J. 2004. Litter production and litter nutrient concentrations in fragmented Amazonian landscape. Ecological Applications, 14: 884-892.

Viana, V.M.; Tabanez, A.A.J.; Batista, J.L.F. 1997. Dynamics and restoration of forest fragments in the Brazilian Atlantic Moist forest. p:351-365. In Laurance, W.F.; Bierregaard, R.O. (eds) Tropical Forest Remnants: Ecology Management and Conservation of Fragmented Communities. The University of Chicago Press Chicago.

Wilkinson, L. 1986. Systat: The system for statistics. Evanston SYSTAT Inc

Williams-Linera, G. 1990. Vegetation structure and environmental conditions of forest edges in Panama. Journal of Ecology, 78: 356-373.

Wu, J.; Huang, J.; Han, X.; Gao, X.; He, F.; Jiang, M.; Jiang, Z.; Primack, R.B.; Shen, Z. 2004. The Three Gorges Dam: an ecological perspective. Ecology Environment, 2: 241-248.

Recebido em 29/01/2011

Aceito em 27/03/2011 